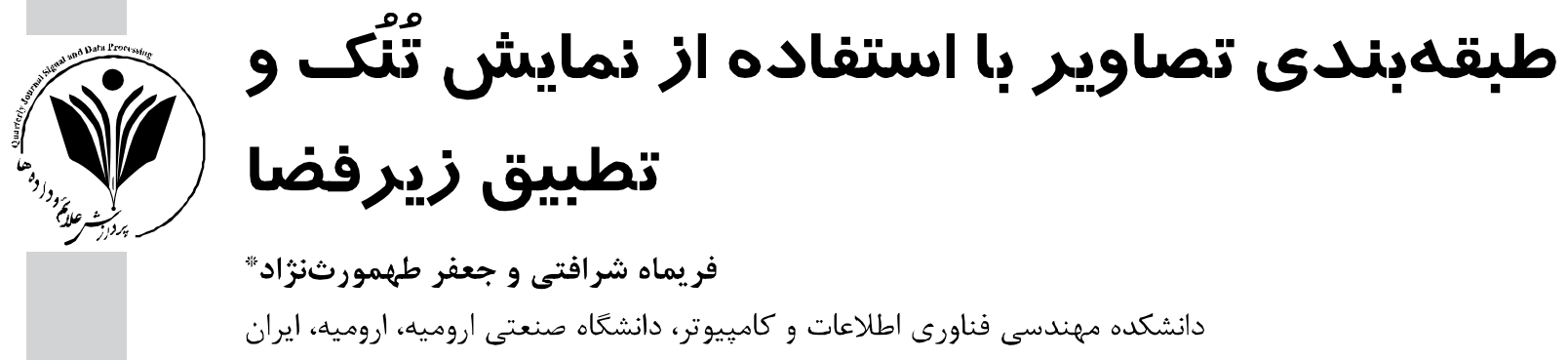

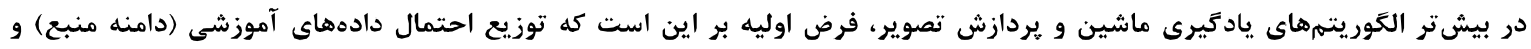

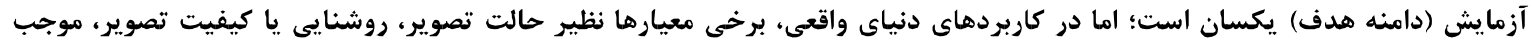

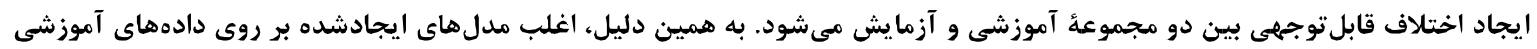

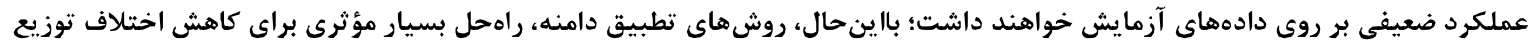

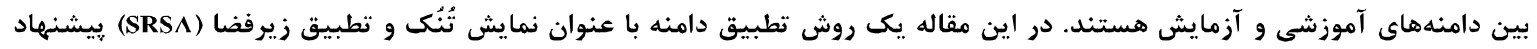

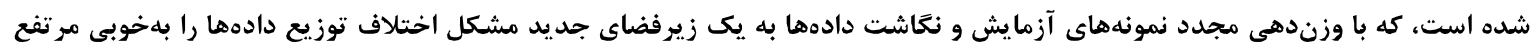

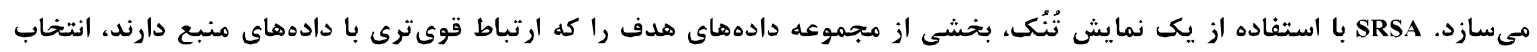

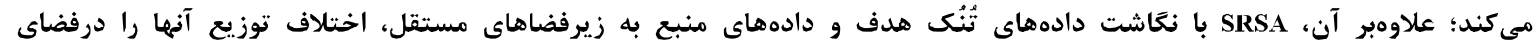

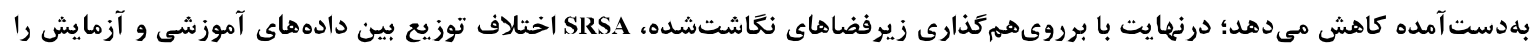

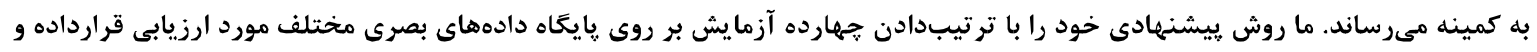

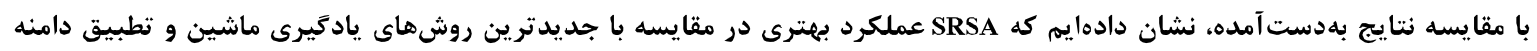

وازَّان كليدى: طبقدبندى تصوير، تطبيق دامنههاى بصرى، نمايش تُنْك، تطبيق زيرفضا.

\title{
Image Classification via Sparse Representation and Subspace Alignment
}

\author{
Farimah Sherafati \& Jafar Tahmoresnezhad*
}

Faculty of IT \& Computer Engineering, Urmia University of Technology, Urmia, Iran

\begin{abstract}
Image representation is a crucial problem in image processing where there exist many low-level representations of image, i.e., SIFT, HOG and so on. But there is a missing link across low-level and highlevel semantic representations. In fact, traditional machine learning approaches, e.g., non-negative matrix factorization, sparse representation and principle component analysis are employed to describe the hidden semantic information in images, where they assume that the training and test sets are from same distribution. However, due to the considerable difference across the source and target domains result in environmental or device parameters, the traditional machine learning algorithms may fail.

Transfer learning is a promising solution to deal with above problem, where the source and target data obey from different distributions. For enhancing the performance of model, transfer learning sends the

* Corresponding author

*نويسندة عهدهدار مكاتبات


knowledge from the source to target domain. Transfer learning benefits from sample reweighting of source data or feature projection of domains to reduce the divergence across domains.

Sparse coding joint with transfer learning has received more attention in many research fields, such as signal processing and machine learning where it makes the representation more concise and easier to manipulate. Moreover, sparse coding facilitates an efficient content-based image indexing and retrieval.

In this paper, we propose image classification via Sparse Representation and Subspace Alignment (SRSA) to deal with distribution mismatch across domains in low-level image representation. Our approach is a novel image optimization algorithm based on the combination of instance-based and feature-based techniques. Under this framework, we reweight the source samples that are relevant to target samples using sparse representation. Then, we map the source and target data into their respective and independent subspaces. Moreover, we align the mapped subspaces to reduce the distribution mismatch across domains. The proposed approach is evaluated on various visual benchmark datasets with 14 experiments. Comprehensive experiments demonstrate that SRSA outperforms other latest machine learning and domain adaptation methods with significant difference.

Keywords: Image classification, Visual domains adaptation, Sparse representation, Subspace alignment.

يك راه حل ساده براى حل اين مشكل جمعآورى

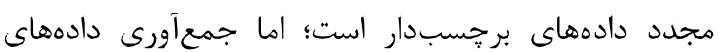

برجسبدار نيازهند صرف هزينه و وقت بسيار بوده و بهترين راه حل ممكن نيست. راه حل ديكر استفاده از دادههاى برجسبدار از منابع ديخر است، كه اين راه حل هم منجربه

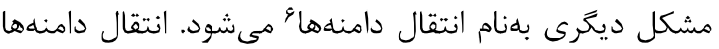
درواقع به معناى اختلاف توزيع در دادههاى آموزشى و آزمايش است كه باعث كاهش كارايى مدل مىشود. براى احى كاهش اثرات انتقال دامنهها بر روى مدل از يكى راه حل حل

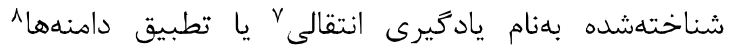

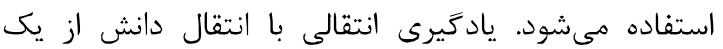

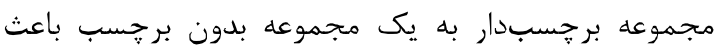
افزايش كارايى مدلهاى طبقلبندى تصاوير مىشود. دركل مسائلى كه در حوزه يادگيرى انتقالى مطرح

مىشوند با توجه به نوع داده مجموعه آزمايش به دو دسته دئه

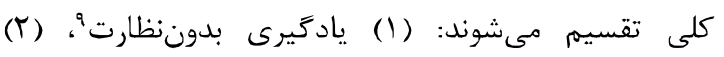

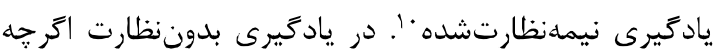

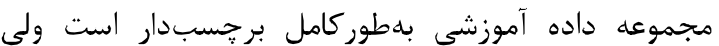

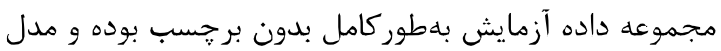

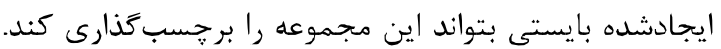

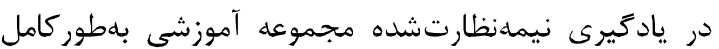

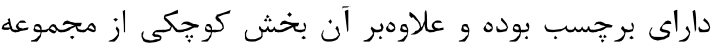

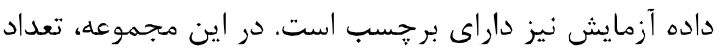

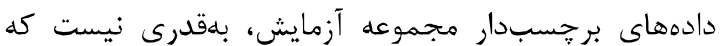
بتوان با استفاده از آن يك مدل دقيق و درست ايجاد كرد.

${ }^{6}$ Domains Shift

${ }^{7}$ Transfer Learning

${ }^{8}$ Domains Adaptation

${ }^{9}$ Unsupervised Learning

${ }^{10}$ Semi-supervised Learning

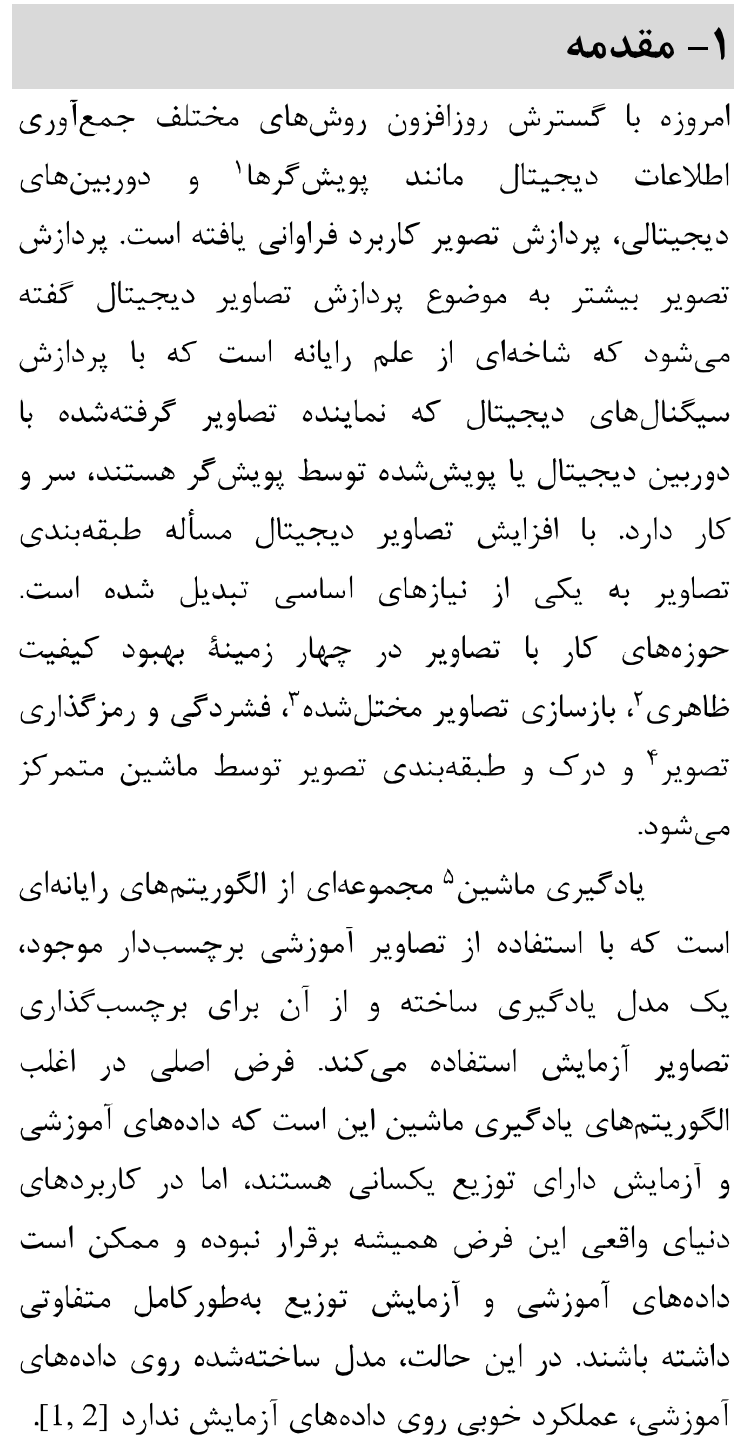

1 Scanncrs

${ }^{2}$ Enhancement

${ }^{3}$ Restoration

${ }^{4}$ Compression and Coding

${ }^{5}$ Machine Learning 
هنبع و هدف به زيرفضاى كمبُعد مبتنىبر نظريه كاهش بُعد و تطبيق زيرفضاهاى جديد انجام مىشود كه توزيع دامنهها را بله يكديخر نزديك مى كند.

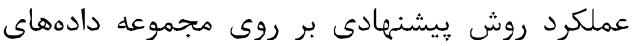
تشخيص اشيا (آفيس و كالتك) و و اعداد دستنويس مورد بررسى قرار گرفته و با روشهاى (MNIST،USPS) مشابه در اين حوزه مقايسه شده است. نتايج بلدستآمده از

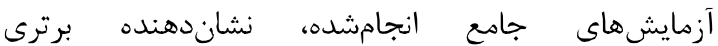
قابلملاحظه روش یيشنهادى است.

ادامه اين مقاله بهصورت زير سازماندهى شده رئس است.

مرورى بر كارهاى كذشته در بخث دوم مقاله و تعاريف در بخش سوم آورده شده است. بخش جههارم روش ييشنهادى، آزمايشهاى جامع انجامكرفته بر روى يايگاهدادههاى مختلف كانف

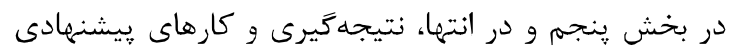
آينده آورده شده است.

\section{r- مرورى بر كارهاى كذشته}

تطبيق و انتقال دامنهها دو مسأله اساسى در يادگيرى ماشين هستند و در سالهاى اخير توجه بسيارى از يزوهش طبيعى و بينايى ماشين بهخود جلب كرده است. روشهاى

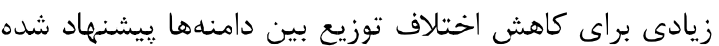
است، ولى با اينحال سه رويكرد كلى در اين حوزه وجود بردي دارد: رويكردهاى مبتنىبر نمونه، رويكردهاى مبتنىبر

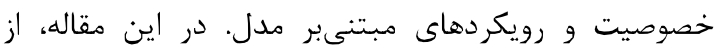
تركيب رويكردهاى مبتنىبر نمونه و مبتنىبر خصوصيت استفاده شده كه در زير بهتفصيل توضيح داده شده است.

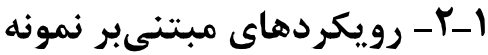

در رويكردهاى مبتنىبر نمونه، هدف، انتخاب نمونههايى از دامنه منبع است كه توزيع نزديكترى با نمونههاى دامنه هدف داشته باشند تا اختلاف توزيع بين دو دامنه كاهش يابد. لندمارك [5] يكى از روشهاى مبتنىبر نمونه است كه براى محاسبه ميزان اختلاف توزيع بين دامنهها از استفاده مىكند و به نمونههاى منبع كه اختلاف توزيع كمترى با نمونههاى هدف دارند، وزن بيشترى اختصاص

${ }^{5}$ Maximum Mean Discrepancy
در جُنين شرايطى از يادگيرى انتقالى جهت انتقال دانش بين دو مجموعه داده استفاده مىشود. در اين مقاله، بر روى لرى مسأله يادكيرى بدون دونظارت تمركز شده است.

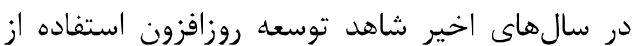
مفهوم نمايش تُنْك ' در كاربردهاى مختلف إِيردازش تصائ تصوير

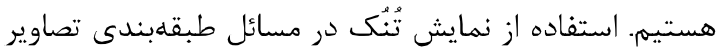

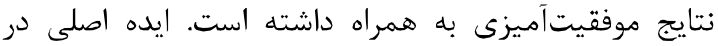

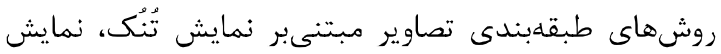

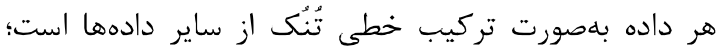
بلكَونهاى كله دادهاى مشابه با داده مورد نظر در اين تركيب خطى بيشترين وزن را به خود اختصاص دهند [3]. در اين مقاله، يك روش بردئ براى تطبيق دامنه بدوننظارت بين دادههاى آموزشى و و آزمايش به بهنام

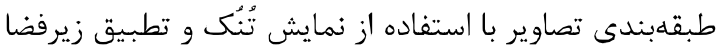

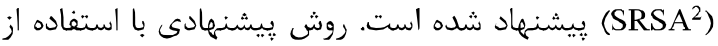

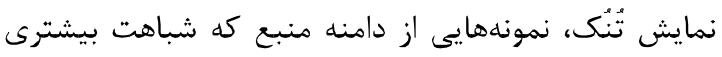
را با نمونههاى دامنه هدف دارند انتخاب مي كند، و با استفاده از فضاى ويزگى دادهها مىباشد، دادههاى انتخابشده از دامنه منبع را به زيرفضاى منبع و دادمهاى دامنه هدف رادئ را به

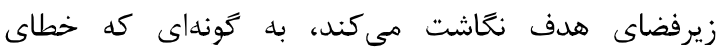
بازسازى ^ دادهها در زيرفضاهاى جديد كمينه باشد. همجنين روش يِيشنهادى براى كاهش تغييرات بين دامنهاى، زيرفضاهاى دامنههاى منبع و هدف را با يكديكر تطبيق مى دهد. اين هدف با يافتن يك ماتريس نكاشت امكانيذير

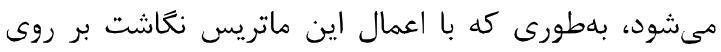
دادههاى انتخابشده از دامنه منبع در زيرفضاى بـ جديد،

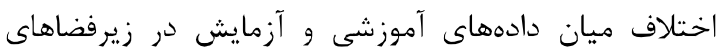

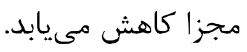
بلهور كلى هر كدام از مراحل روش ييشنهادى شامل فرايندهاى زير جهت ايجاد تطبيق بين دامنهایى منبع و هدف هستند: () برخلاف روشهاى ديخر كه از همه دادههاى دامنه منبع براى ساخت طبقلبند استفاده مى كنند،

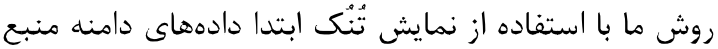

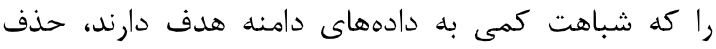
مى كند؛ سيس، دادههاي هدف را بر اساس تركيب خطى

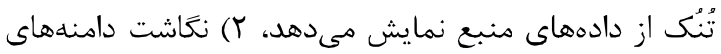

\footnotetext{
${ }^{1}$ Sparse Representation

${ }^{2}$ image classification via Sparse Representation and Subspace Alignment (SRSA)

${ }^{3}$ Principal Component Analysis

${ }^{4}$ Reconstruction error
} 
نمونهoاى هر ردم، دامنها را به زيرفضاى جديد نعاشت

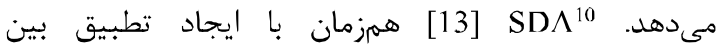
زيرفضاهاى دامنه منبع و هدف، اختلاف توزيع بين دامنهها را از طرىق تطبيق واريانس مؤلفههاى اساسى دامنهها به ونه كمينه مىرساند. حاشيهاى و شرطى بين دامنهها، يك نمايش كمبُعد از

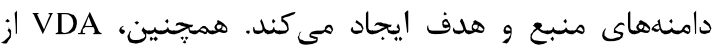

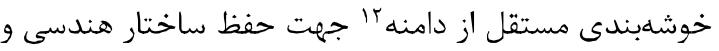
آمارى بين دامنهها در فضاى جديد استفاده مى كند.

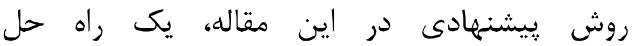

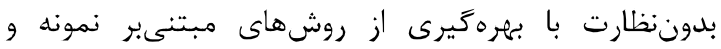

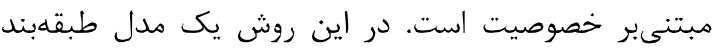
توسط كاهش اختلاف توزيع بين نمونههاى دامنه منبع و هدف با استفاده از نمايش تُنُك و همجينين با استفاده از تطبيق زيرفضاها ايجاد ميشود كه داراى كمينه خطاى ويشبينى است.

\section{r- تعاريف و مفاهيم اوليه}

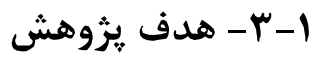

تطبيق دامنه يكى از مسائل مطرح در حوزه يادگيرى ماشين

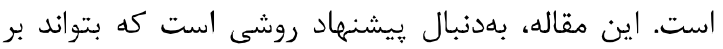
محدوديتهاى الخوريتمهاى يادگيرى ماشين كلاسيك غلبه

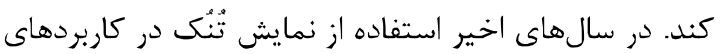
مختلف بردازش تصوير رواج زيادى بيدا كرده است؛ بنابراين،

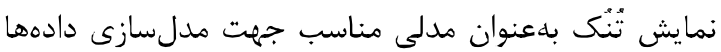
در فضاى جديد استفاده مىشود.

\section{r-r-r تعريف دامنه "r و وظيفه}

در يادگيرى انتقالى هر دامنه از دو مفهوم زير تشكيل شده

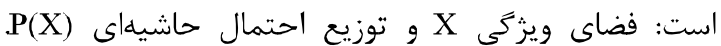
بنابراين دامنه D بهصورت D=\{X,P(X)\} نمايش داده مىشود. بدين ترتيب، زمانى دو دامنه متفاوت هستند كه يا فضاى ويزگى و يا توزيع حاشيهاى متقاوتى داشته باشند. براى هر دامنه D يك وظيفه T وجود دارد كه شامل مجموعة برجسب Y Y و تابع يِيشبينى (x)

${ }^{10}$ Subspace Distribution Alignment

11 Visual Domain Adaptation via transfer feature learning

${ }^{12}$ Domain invariant clustering

${ }^{13}$ Domain

${ }^{14}$ Task
6, ] (SRCl) طبقهبندى كننده مبتنىبر نمايش تُنْك 7] يكى ديخر از روشهاى مبتنىبر نمونه است كه در سامانههاى تشخيص جهره نتايج قابلتوجهى را بهدست آورده است. ايده اصلى SRC به اين صورت است كه هر تصوير لتهري جهره بهصورت تركيب خطى تُنُك از ساير تصاوير جهره نمايش داده مىشود. انتخاب تصاوير با استفاده از ضرايب

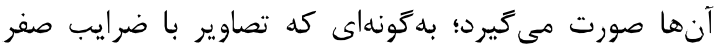
حذف شده و تصاويرى كه ضرايب غيرصفر و وزن بيشترى به آنها تعلق گرفته است، انتخاب مى مئدوند. روش دامنههاى منبع و هدف، با يافتن يكى ماتريس انتخاب، براب نمونهاى منبع مشابه با نمونههاى هدف را انتخاب مى كند و

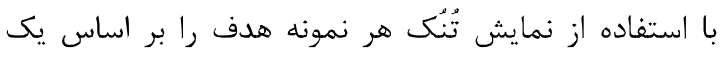

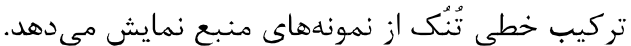

\section{r-r - رويكردهاى مبتنى بر خصوصيت}

در رويكردهاى مبتنىبر خصوصيت، فضاى ويثزَى ب براى

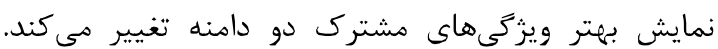

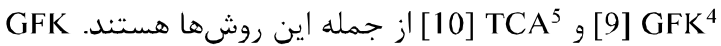
دادههاى منبع و هدف را بر روى منيفلد گرسمن و نغاشت

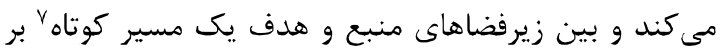
روى منيفلد ايجاد مى كند تا تغييرات دامنه از منبع تا هدف

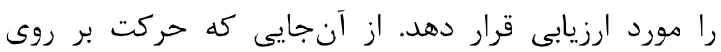
مسير كوتاه بايستى بهصورت روان و وِيوسته باشد، اندازه زيرفضا را كوجى درنظر مى گيرد كه موجب ازبينرفتن بخشى از دادههاى ورودى مى شود. TCA اختلاف توزيع

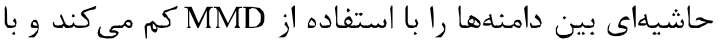
بيشينهكردن ميزان واريانس دادهها، ويزگ

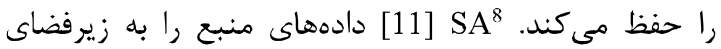
منبع و دادههاى هدف را به زيرفضاى هدف نثاشت مى كند،

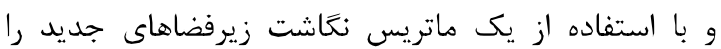

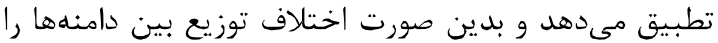
كاهش مى دهد. SCA نمونهها در ردههاى مختلف و كمينهسازى اختلاف بين

\footnotetext{
' Sparse Representation-based Classifier

${ }^{2}$ Sample Sclection Sparse Coding

${ }^{3}$ Feature Space

${ }^{4}$ Geodesic Flow Kernel

5 Transfer Component Analysis

${ }^{6}$ Grassman Manifold

${ }^{7}$ Geodesic

${ }^{8}$ Subspace Alignment

${ }^{9}$ Scatter Component Analysis
} 
دامنه منبع با

نمايش داده مىشوند كه در آن $D_{T}=\left\{X_{T}, Y_{T}\right\}$ و بهترتيب دادههاى منبع $X_{T} \in R^{d_{T} *_{n} n_{T}} \quad, X_{s} \in R^{d_{s} *^{*} n_{s}}$ هدف هستند , $Y_{T} \in R^{n_{T} * 1}, Y_{S} \in R^{n_{S} * 1}$ منبع و هدف، d $d_{S}$ هدف، $n_{S} n_{T} n_{T}$ باترتيب نشاندهنده تعداد نمونههاى منبع و هدف است. فرض شده دامنههاى منبع و هدف يكسان است. r-r

براى بلهستآوردن زيرفضاهاى مشترك يا مستقل مى توان از

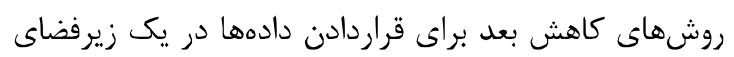
تعبيهشدة جديد استفاده كرد. تجزيه مؤلفههاى اصلى برى برى يك روش كاربردى براى استخراج ويزگى از دادهها

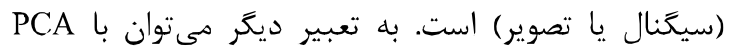
كاهش بعد انجام داده و ويزگى هاى جديد استخراج كرد.

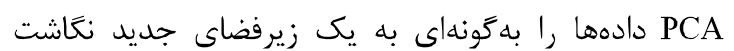
مى كند كه ساختار اصلى دادهها حفظ شود. بدين ترتيب، دادهها بر روى اجزاى اصلى خود نتاشت مىشوند كه شامل اجزايى است كه داراى واريانس بالايى هستند. از بين اجزاى بهدستآمده، اجزايى كه داراى حداكثر واريانس باشند بهعنوان اجزاى اصلى جهت نحاشت دادهها به فضاى كمبعد استفاده مىشوند.

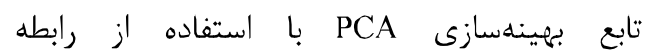
$H=I_{n_{s}+n_{t}}-$ كه بهدس $\max _{A^{T} A=I} \operatorname{tr}\left(A^{T} X H X^{T} A\right)$

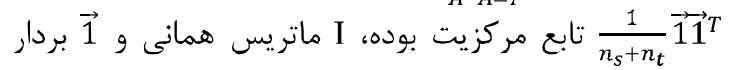
ستونى از يكها است [4] tr نشاندهنده حاصل جمع عناصر قطر اصلى ماتريس است.

\section{F}

در اين مقاله يك روش نوين با عنوان SRSA ييشنهاد شده

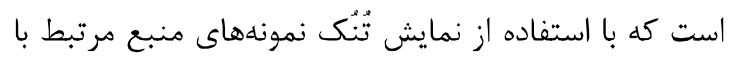
نمونههاى هدف را انتخاب كند. SRSA يك نمايش كمربعد براى نمونههاى منبع انتخابشده و نمونهاى هدف، ايجاد مى كند و براى كاهش بعد دادهها از PCA استفاده مى كند. سيس، SRSA زيرفضاهاى ايجادشده منبع و هدف را با يكديكر تطبيق داده تا توزيع آنها بر روى يكديگر منطبق

$$
\text { شود. }
$$

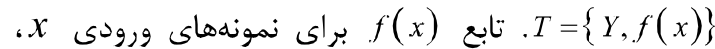

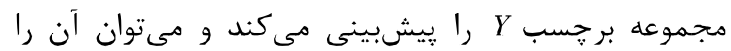
بلهورت توزيع احتمال شرطى ترتيب، زمانى دو وظيفه متفاوت هستند كه يا مجموعه برجسب و يا تابع توزيع احتمال شرطى متفاوتى داشته

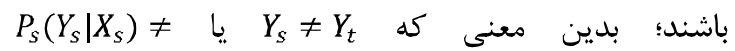
$P_{T}\left(Y_{T} \mid X_{T}\right)$

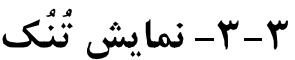

امروزه نمايش تُنُك بهعنوان ابزارى قوى و كارآمد براى نمايش سيخنالها تبديل شده و در كاربردهايى همجون نمونهبردارى، بازيابى و طبقهبندى تصاوير مورد استفاده قرار زرفته است. هدف اين نوع نمايش، تقريب دادههاى آزمايش بايث

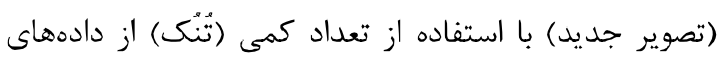

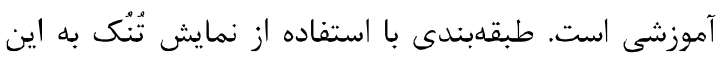
صورت است كه دادهاى آموزشى بلعنوان ديكشنرى ' درنظر كرفته مىشوند و دادههاى هدف بهصورت تركيب خطى از آنها نمايش داده مىشوند. همانطور كه در شكل (1) نشان

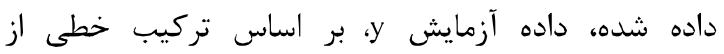
ديكشنرى (D) نمايش داده شده است.

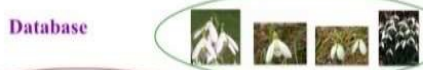
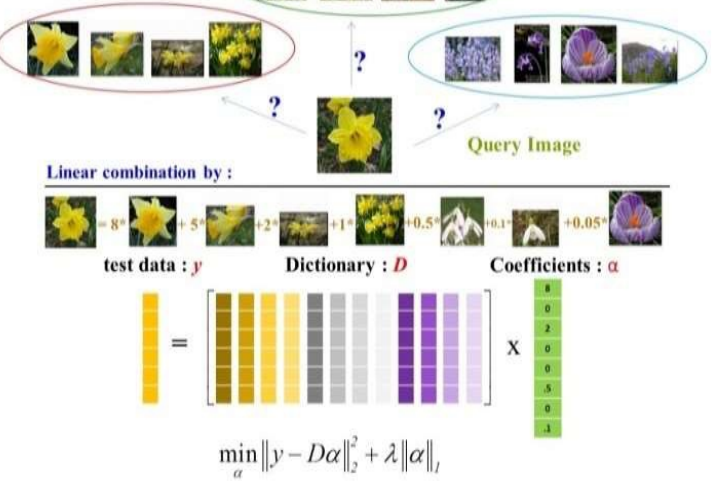

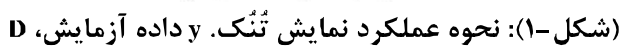

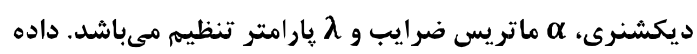

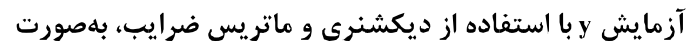
تركيب خطى از ديكشنرى نمايش داده مى لشود.

(Figure-1): Sparse representation methodology. y is test data, D shows dictionary, $\alpha$ is the coefficient matrix and $\lambda$ illustrates the tuning parameter. Test data $y$ is represented by a linear combination of the dictionary and coefficient matrix. 
بهدستآمده از هر دامنه را با يكديكر تطبيق مىدهد كه براى اين هدف از استراتثى تطبيق زيرفضا استفاده مى كند.

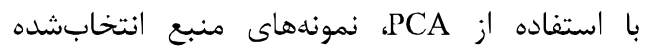
و نمونهاى هدف (Xs1) داده مىشوند؛ سيس، زيرفضاهاى منبع (P) با استفاده از ماتريس نخاشت Mبا يكديگر تطبيق داده مىشوند. ماتريس نغاشت M با حداقل مازى واكرايى ماتريس

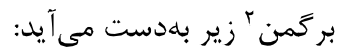

$F(M)=\left\|P_{S} M-P_{T}\right\|_{F}^{2}$

فرم بسته رابطه (r) را مىتوان بهصورت زير نوشت:

$M^{*}=\operatorname{argmin}_{M}(F(M))$

كه ${ }^{*}$ مقدار بهينه ماتريس تطبيق را نشان مى مهد.

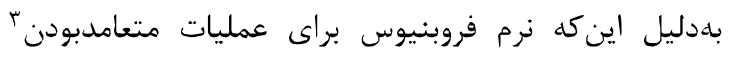

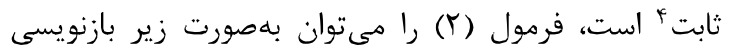

$F(M)=\left\|P_{S}^{\prime} P_{S} M-P_{S}^{\prime} P_{T}\right\|_{F}^{2}=\left\|M-P_{S}^{\prime} P_{T}\right\|_{F}^{2}$

با توجه به رابطه (f)، مىتوان نتيجه كرفت كه

بهينه با استفاده از رابطه باده $M^{*}=P_{S}^{\prime} P_{T}$ است كه $X_{a}=P_{S} P_{S}^{\prime} P_{T}$ هدف است.

ماتريس نكاشت ${ }^{*}$ سامانه مختصات زيرفضاى منبع

را با سامانه مختصات زيرفضاى هدف، با استفاده از بردارهاى يايه منبع تطبيق مى دهد. عملكرد روش تطبيق زيرفضا در

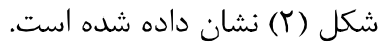

\section{SRSA الكوريتم روش-F-f}

با مشتق مقيرى از رابطه (1) و مساوى قراردادن آن با صفر،

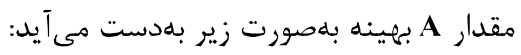

$\mathbf{\Lambda}=\left(\rho \mathbf{R}+\mathbf{X}_{\mathbf{S}}^{T} \mathbf{X}_{\mathbf{s}}\right)^{-1} \mathbf{X}_{\mathbf{S}}^{T} \mathbf{X}_{T}$

كه در رابطه بالا، وابسته به A است و A با يك روش تكرارى بهدست مى آيد.

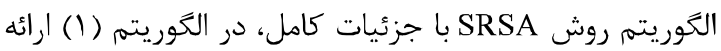

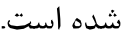

${ }^{2}$ Bregman matrix divergence

${ }^{3}$ Orthonormal

${ }^{4}$ Invariant

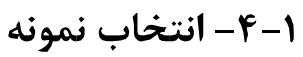

براى انتخاب نمونهها از يك نمايش تُنُك استفاده

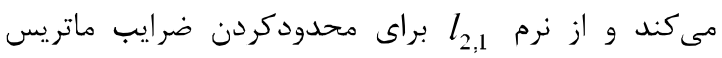
انتخاب A بهره مىبرد [15]. SRSA با استفاده از رابطه زير، ماتريسى بهدست مى آورد كه اختلاف توزيع بين دادههاى منبع و هدف را كمينه ميسازد و مىتوان هر نمونه هدف ران بهصورت تركيب خطى از كمينه نمونههاى منبع نمايش داد. $\min _{\mathbf{A}}\left\|\mathbf{X}_{T}-\mathbf{X}_{\mathbf{s}} \mathbf{A}\right\|_{F}^{2}+\rho\|\mathbf{A}\|_{2,1}$

كه در اين رابطه، .||. || نرم فروبنيوس' و ماتريس يكى ماتريس تُنُك است، كه با استفاده از مسأله بهينهسازى بالا بهدست مى آيد و م يارامتر تنظيم براكندكى لئى است. با استفاده از نرم $l_{2,1}$ هر سطر ماتريس همزمان صفر يا غيرصفر مىشود كه سطرهاى غيرصفر بهعنوان نمونههاى منبع مرتبط با نمونهاى هدف انتخاب و نمونهاى منبع انتخابشده با Xم1 Xمايش داده مىشوند.

\section{r-F- توليد زيرفضا}

با وجود اينكة دادههاى منبع و هدف در فضاى Dُبعدى يكسان قرار دارند، با اين حال توزيع حاشيهاى متفاوتى دارند. بنابراين، دادههاى منبع و هدف با استفاده از PCA به زيرفضاهاى مربوط به خود نكاشت داده مىشوند تا اختلاف

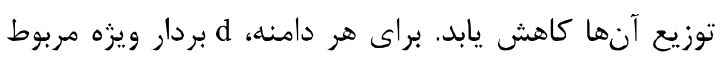
به بزرگترين مقادير ويثه PCA انتخاب مىشوند. اين بردارهاى ويزه بلهنوان زيرفضاهاى منبع و هدف استفاده مىشوند كه بهترتيب با P و . $\left(\mathbf{P}_{\mathbf{s}}, \mathbf{P}_{\mathbf{T}} \in \mathbf{R}^{\mathbf{D} * \mathbf{d}}\right)$

\section{r-f \\ زيرفضا}

استراتثى اصلى در زيرفضاى مبتنىبر تطبيق داهنه، اينگونه است كه دادههاى منبع و هدف به يك زيرفضاى مشترك

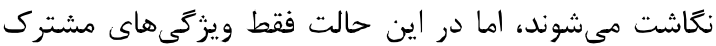
از دو دامنه استخراج مىشوند و بعضى از اطلاعات كه ماته

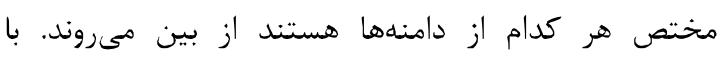
اينحال، SRSA دادههاى منبع و هدف هر كدام از دامنهها را به زيرفضاى مربوط به خود نغاشت داده و سيس، زيرفضاهاى

${ }^{1}$ Frobenius norm 


\section{|-هـ- مجموعهدادههاى دنياى واقعى}

كارايى روش پيشنهادى در اين مقاله، بر روى دو نوع

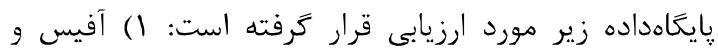

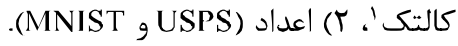

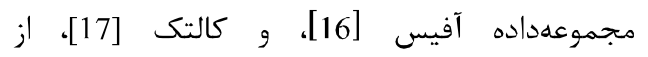
مجموعلدادههاى بسيار مشهور براى تطبيق دامنه هستند.

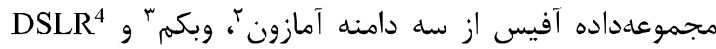
تشكيل شده است كه شامل تصاويرى با كيفيت، رنت و

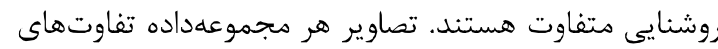

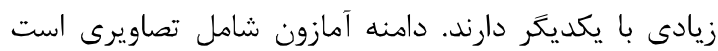

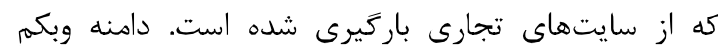
شامل تصاويرى با وضوح هايين است كله توسط دوربينهاى باري كمكيفيت وب زرفته شدهاند و دامنه DSLR شامل تصاويرى با وضوح بالا است كه توسط دوربينهاى ديجيتالى حرفهاى

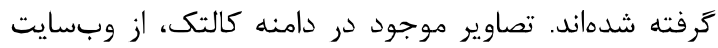

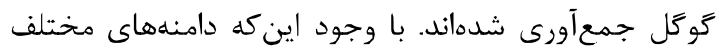

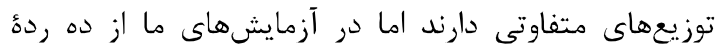

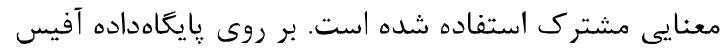

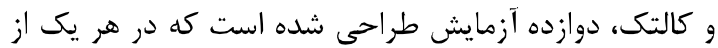
اين آزمايشها يكى از مجموعه دادهها (بهعنوان نمونه وبكمم)،

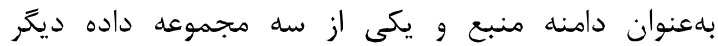
بلهنوان دامنه هدف انتخاب مىشوند.

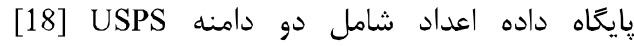

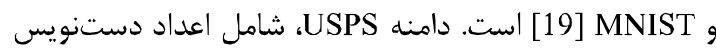
يويششده از نامههاى اداره يست آهريكا در اندازههاى

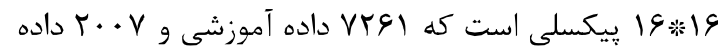
آزمايش دارد. دامنه MNSIT، شامل اعداد دستنويس

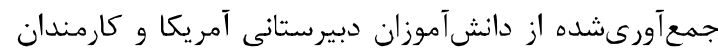

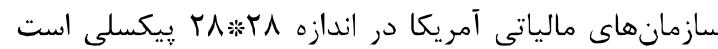
كه شامل ششهزار داده آموزشى و هزار داده آزمايش است.

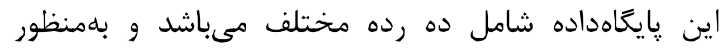

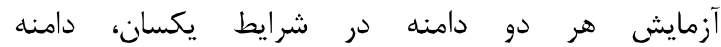
ايجاد شده است كه بلهُور USPS_vs_MNIST(U_M)

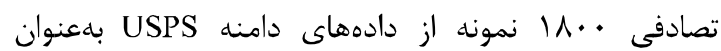

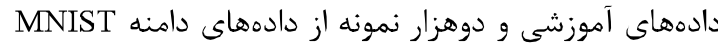

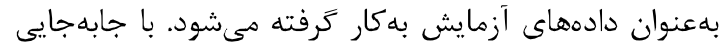

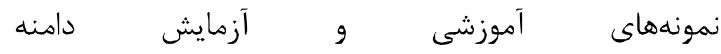

${ }^{1}$ Office and Caltech

${ }^{2}$ Amazon

${ }^{3}$ Webcam

${ }^{4}$ Digital single-lens reflex
Algorithm 1. Algorithm of image classification via sparse representation and subspace alignment (SRSA)

Input: Source data $X_{\mathrm{S}}$, Target data $\mathrm{X}_{\mathrm{T}}$, Source labels $L_{S}$, Subspace dimension d

Parameter: Regularization parameters $\rho$

Output: Predicted target labels $L_{T}$

$1:$ Repeat until the maximum number of iterations is reached

2: Compute selection matrix A via solving Eq. (5).

3: Compute diagonal matrix $\mathbf{N}=\frac{1}{2\left\|A^{i}\right\|_{2}}$ based on A.

4: END Repeat

5: Return $L_{T}=k N N\left(X_{S} A P_{S} P_{S}^{\prime} P_{T}, X_{T} P_{T}, L_{S}\right)$

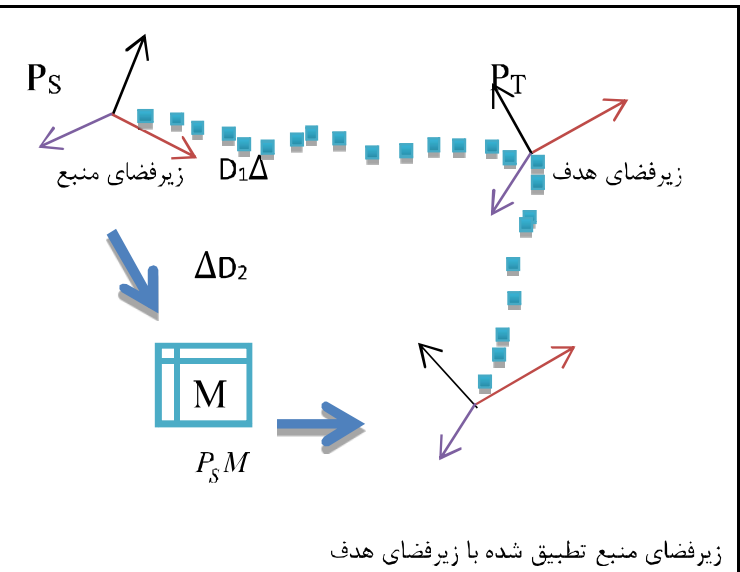

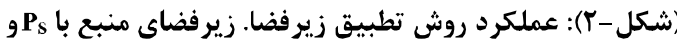

زيرفضاى هدف با P نشان داده شده است. زيرفضاى منبع با

زيرفضاى هدف تطبيق داده شده و

(Figure-2): The performance of the subspace matching method.

The source subspace is represented by $P_{\mathrm{s}}$ and the target subspace is showed by $P_{\mathrm{T}}$. The source subspace is aligned with target subspace via $X_{a}=P_{S} M$.

در الخوريتم SRSA، هدف بيشبينى برجسبهاى نمونهاى دامنه هدف با استفاده از نمايش تُنك و تطبيق زيرفضا است. SRSA در ابتدا نمونهاى منبع را با استفاده از ماتريس انتخاب A بهدستآورده، سيس، زيرفضاهاى هر كدام از دامنههاى منبع و هدف را بهطور مجزا محاسبه كرده و با يكديكر تطبيق مى مهد و درنهايت با استفاده از طبقهبند برجسب نمونهاى هدف را ييشبينى مى كند. ه- تنظيمات اوليه محيط آزمايش

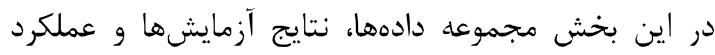

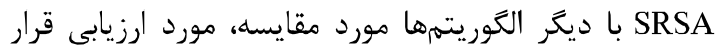
كرفته است. 


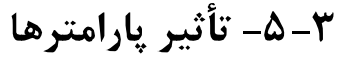

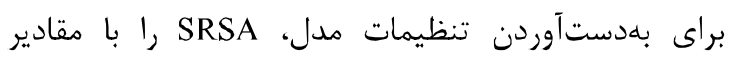

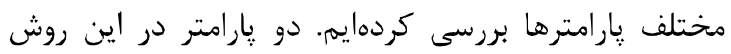

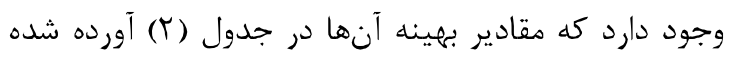

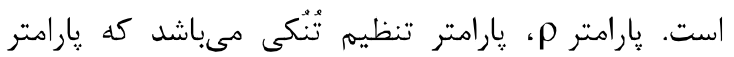
تأثيركذار در انتخاب نمونههاى منبع است و تعداد نمونههاى

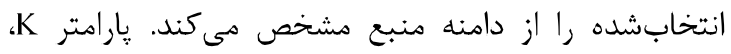

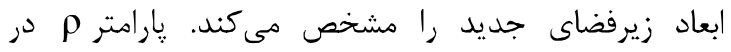

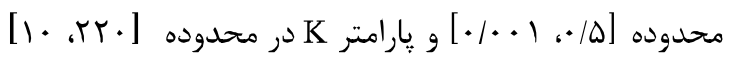

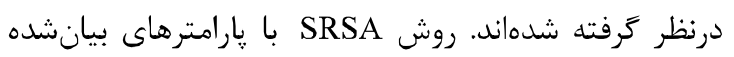

$$
\text { بر روى جهارده مجموعهداده مورد آزمايش قرار مى كيرد. }
$$

دقت طبقلبندى و تعداد نمونههاى انتخابشده با

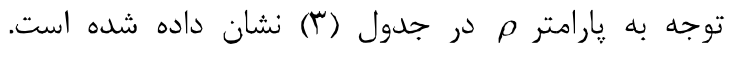

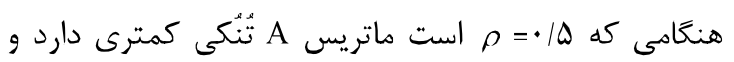

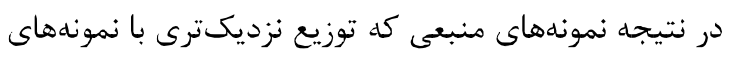
هدف دارند انتخاب مىشوند.

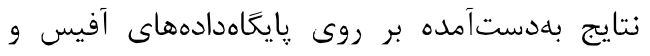
كالتك در شكل (f) نشاندهنده اين است كه بإيخاهداده

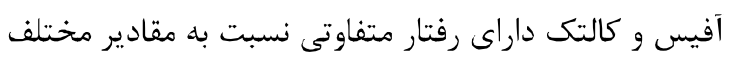
يارامتر K هستند. براى بهدست آوردن مقدار محدوده بهينه

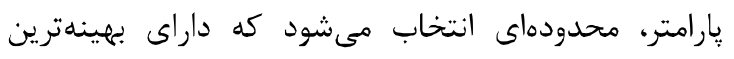

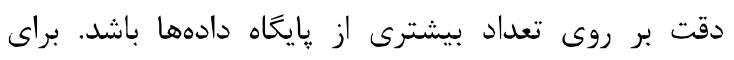

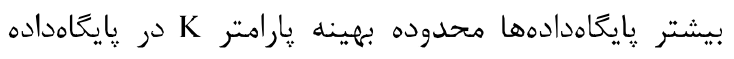

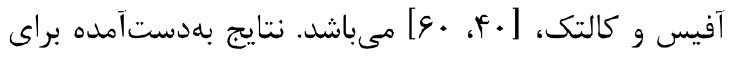

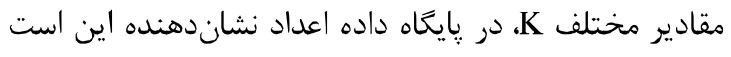

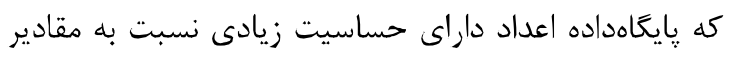

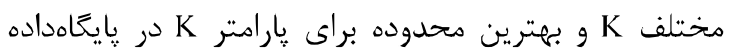

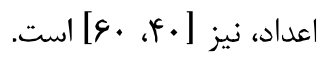

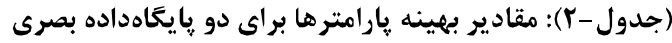

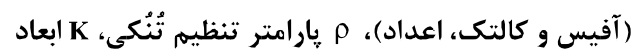

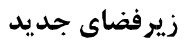

(Table-2): Optimal parameters for two visual datasets ( office $\&$ Caltech, digits), $\rho$ is the sparsity parameter and $K$ is

the new subspace dimension
\begin{tabular}{|c|c|c|c|}
\hline SRSA & $l_{1}$ norm & Orj & S-T \\
\hline 54.35 & 53.95 & 54.40 & U-M \\
\hline 68.56 & 66.11 & 66.44 & M-U \\
\hline 61.46 & 60.03 & 60.42 & Avg \\
\hline
\end{tabular}

براى يك آزمايش ديكر ايجاد MNIST_vs_USPS(M_U)

بهطور كلى كارايى الكوريتم بيشنهادى بر روى

جهارده مجموعه تصاوير بين دامنهاى مختلف مورد ارزيابى لئى

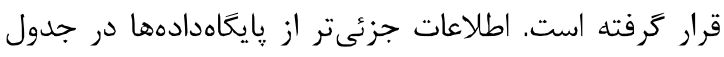

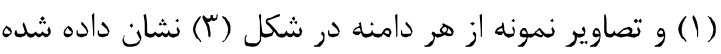

(جدول -1): معرفى هايگًاهدادهها

\begin{tabular}{|c|c|c|c|c|}
\hline اختصار & كلاس تعداد & تعداد ابعاد & نمونهها & يايگاه داده \\
\hline $\mathrm{U}$ & 10 & 256 & 1800 & USPS \\
\hline $\mathrm{M}$ & 10 & 256 & 2000 & MNIST \\
\hline $\mathrm{A}$ & 10 & 800 & 958 & Amazon \\
\hline $\mathrm{W}$ & 10 & 800 & 295 & Webcam \\
\hline $\mathrm{D}$ & 10 & 800 & 157 & DSLR \\
\hline $\mathrm{C}$ & 10 & 800 & 1123 & Caltech 256 \\
\hline
\end{tabular}

(Table-1): The datasets

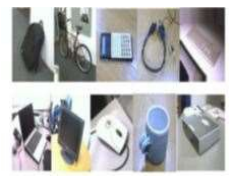

Webcam

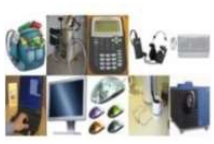

Caltech

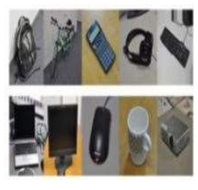

DSLR

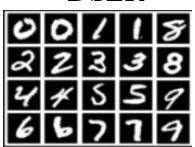

MNIST
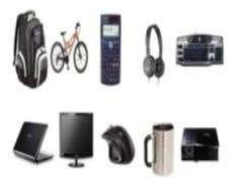

Amazon

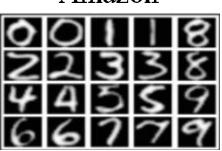

USPS
(شكل - r): تصاوير نمونه از يايكاهدادههاى آفيس و

$$
\text { كالتك و اعداد }
$$

(Figure-3): Sample images from Office \& Caltech and digits datasets

\section{r-ه- مفروضات بيادهسازى}

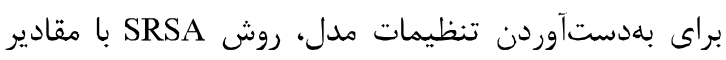

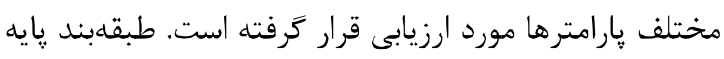

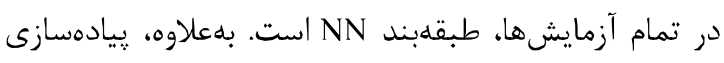

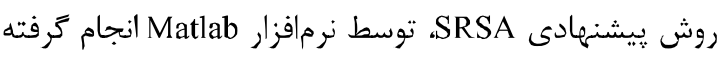

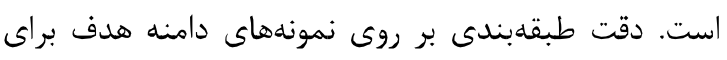

$$
\text { مقايسه الكوريتمها توسط رابطه زير محاسبه مىشود: }
$$

Accuracy $=\frac{\left|\left\{x: x \in D_{t} \wedge f(x)=y(x)\right\}\right|}{n_{T}}$

كه هدف، تابع پيشبينى، برجسب واقعى داده و تعداد نمونههاى 
دقت مدل دارد. استفاده از همه نمونههاى منبع كارايى مدل

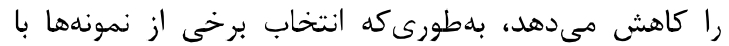

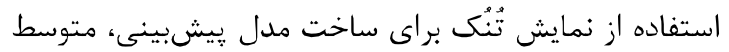

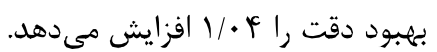
همجنين، همانطور كه در جدول نشان داده شده

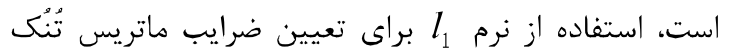

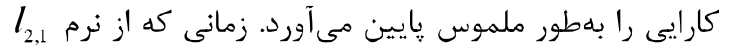
استفاده شود، بهدليل اينكه نمونههاى منبع مرتبط با هدف

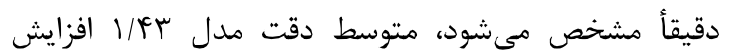

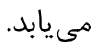
ه-ه - مقايسه با الكوريتمهاى موجود الخوريته SRSA با هشت الخوريتم زير مورد مقايسه قرار

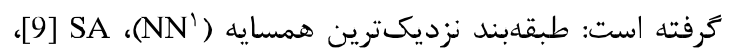

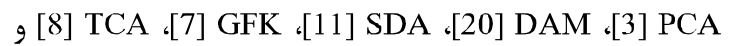
[10] SCA بهدليل اينكه تمامى روشهاى نامبردهده (بهجز NN

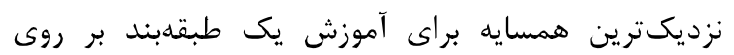

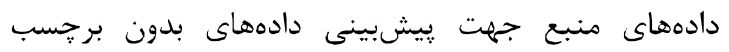
دامنه هدف استفاده مى شود. دقت طبقهبندى SRSA و هشت روش ديخر بر روى

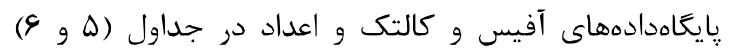
نشان داده شده است. همانطور كه مشاهده مى شود

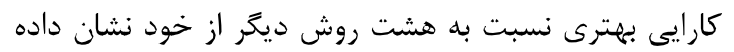

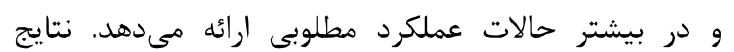

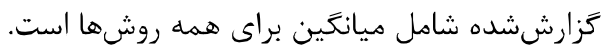

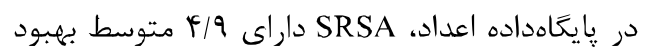

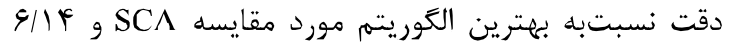

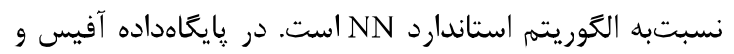

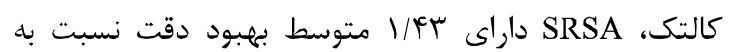

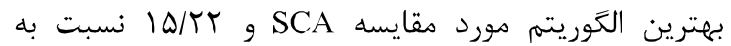
الكوريتم استاندارد NN است. در مر ادامه روشها بلصورت جزئى مقايسه مى كنيم. يك روش كاهش بُعد است كه يك فضاى PCA PCA

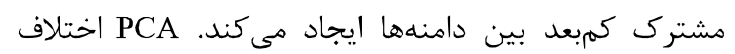
توزيع بين دامنهها را خندان كاهش نمى دهد و و عملكرد إنداد ضعيفى نسبت به ديكر التَوريتمهاى تطبيق دامنه نشان

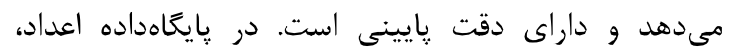

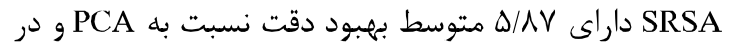

${ }^{1}$ Nearest neighbor

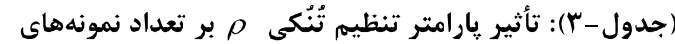
انتخابشده از دامنه منبع در يا يَّاهداده اعداد

(Table-3): The effect of sparsity regularization on the number of selected samples from the source domain on the digit dataset

\begin{tabular}{|c|c|c|c|c|c|c|}
\hline 0.5 & 0.1 & 0.05 & 0.01 & 0.005 & 0.001 & $\rho$ \\
\hline 54.35 & 54.40 & 54.40 & 54.40 & 54.40 & 54.40 & $\begin{array}{c}\rho \text { متوسط } \\
\text { U-M }\end{array}$ \\
\hline 1780 & 1800 & 1800 & 1800 & 1800 & 1800 & U-M \# \\
\hline 68.56 & 66.44 & 66.44 & 66.44 & 66.44 & 66.44 & $\begin{array}{c}6 \text { دقوس } \\
\text { د-U }\end{array}$ \\
\hline 1366 & 2000 & 2000 & 2000 & 2000 & 2000 & M-U \# \\
\hline
\end{tabular}

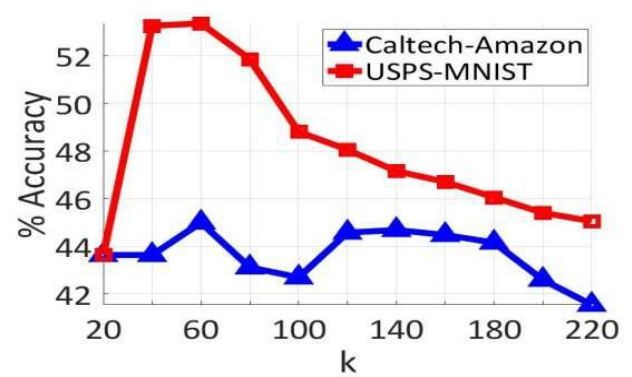

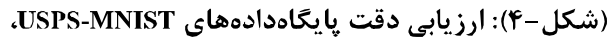

k با مقادير مختلف يارامتر Caltech-Amazon

(Figure-4): USPS-MNIST, Caltech-Amazon datasets accuracy assessment with different values of $k$ parameter

$$
\text { F- F- ضرورت هر يارامتر در الكوريتم }
$$

در اين بخش، ضرورت دو پارامتر بر روى يايغاهداده اعداد

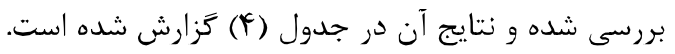

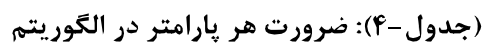

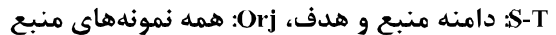

\begin{tabular}{|c|c|c|}
\hline$\rho$ & K & يارارتر ها \\
\hline 0.5 & 50 & كالتيس و \\
\hline 0.5 & 50 & اعداد \\
\hline
\end{tabular}

(Table-4): The necessity of each parameter in the algorithm

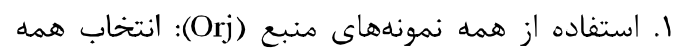

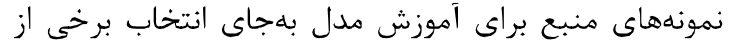
آنها.

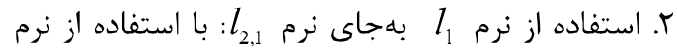
A l $_{1}$

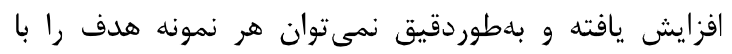

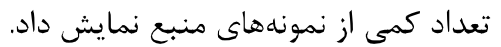

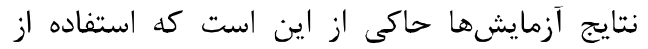

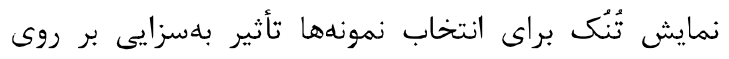


حاشيهاى بين دامنههاى منبع و هدف به كمينه مىرسد، اما بهدليل اينكه زيرفضاهاى نغاشتشده داراى ابعاد بسيار كمى است، باعث از بينرفتن بخشى از داده شده و نمايش خوبى ريى

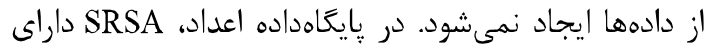

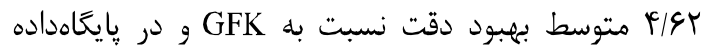
آفيس و كالتك، داراى PF/ F متوسط بهبود دقت است. از جمله دلايل بهبود اين است كه در روش SRSA يك زيرفضا

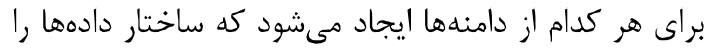

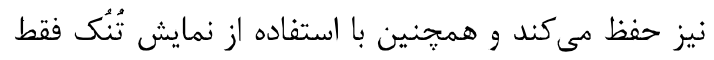
از برخى از نمونههاى دامنه منبع براى ساخت طبقدبند استفاده مى كند.

نيز يكى از روشهاى كاهش بعد در تطبيق بين

دامنهها است كه زيرفضاهاى بلهدستآمده را با يكديخر

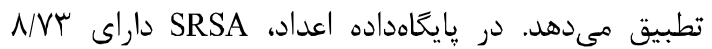
متوسط بهبود دقت نسبت به SA و در :إيخاهداده آفيس و كالتك، داراى 1/AV متوسط بهبود دقت است. دليل بهبود قابلملاحظه SRSA نسبت به SA اين است كه SRSA از نمايش تُنْك براى انتخاب نمونههاى منبع استفاده مى كند.

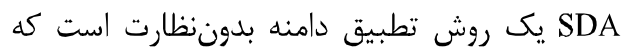

شامل تطبيق توزيع به تطبيق زيرفضا است كه علاوهبر كاهش اختلاف بين دو زيرفضا، اختلاف داده را نيز كم مىكند. در يايگاهداده اعداد، SRSA داراى $11 /$ متوسط بهبود دقت نسبت به SDA و در يايخاهداده آفيس و كالتك، داراى V/V متوسط بهبود دقت و عمدهترين دليل برترى

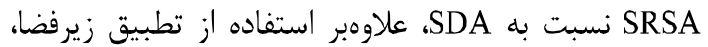
استفاده از نمايش تُنُك براى انتخاب نمونهها است.

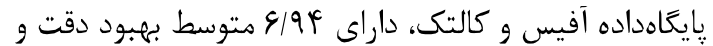
عمدهترين دليل برترى SRSA نسبت به PCA استفاده از تطبيق زيرفضا براى كاهش اختلاف بين دامنهها است. يك روش تطبيق خصوصيات است كه با TCA

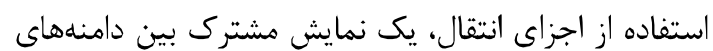
منبع و هدف ايجاد مىكند كه در نمايش جديد، اختلاف توزيع حاشيه اى بين دامنههاى منبع و هدف كاهش مي يابد. در اين روش به اختلاف توزيع شرطى بين دامنه هاى منبع و

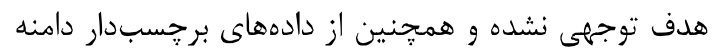
منبع در ايجاد فضاى جديد استفاده نمىشود؛ درحالى كة در روش SRSA ، علاوهبر كاهش اختلاف توزيع حاشيهاى بين دامنهها، از برجسبهاى نمونههاى دامنه منبع براى ايجاد تفكيكيذيرى بهتر بين ردهها استفاده شده است. به همين دليل، عملكرد روش SRSA نسبت به روش TCA بهتر است.

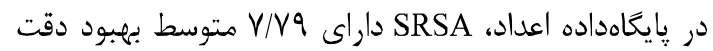

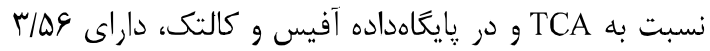
متوسط بهبود دقت است.

يك روش تطبيق دامنه جندمنبعى است كه DAM

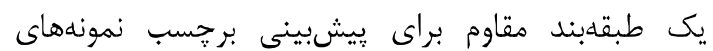

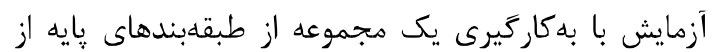
بيش يادگرفتهشده ايجاد مى كند. در زيايخاهداده اعداد، داراى IT/V متوسط بهببود دقت نسبت به DAMSA

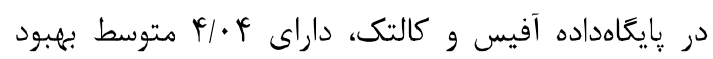
دقت است.

در روش GFK، زيرفضاهايى از دامنههاى منبع و

هدف ايجاد مىشود كه در اين زيرفضاها اختلاف توزيع

(جدول-ه): دقت (\%) طبقدبند در يايگاهداده آفيس و كالتك

(Table-5): Classification accuracy on Office \& Caltech dataset

\begin{tabular}{|c|c|c|c|c|c|c|c|c|c|}
\hline SRSA & $\begin{array}{c}\mathrm{SCA} \\
(2016) \\
\end{array}$ & SDA (2015) & SA (2013) & GFK (2012) & $\begin{array}{l}\text { DAM } \\
(2012)\end{array}$ & TCA (2011) & PCA (2002) & NN & Dataset \\
\hline 44.57 & 45.62 & 49.69 & 49.27 & 41.02 & 42.69 & 45.82 & 36.95 & 23.7 & C_A \\
\hline 39.32 & 40 & 38.98 & 40 & 40.68 & 34.58 & 30.51 & 32.54 & 25.76 & C_W \\
\hline 52.87 & 47.13 & 40.13 & 39.49 & 38.85 & 33.12 & 35.67 & 38.22 & 25.48 & CD \\
\hline 38.91 & 39.72 & 39.54 & 39.98 & 40.25 & 35.35 & 40.07 & 34.73 & 26 & A_C \\
\hline 40.68 & 34.92 & 30.85 & 32.22 & 38.98 & 31.86 & 35.25 & 35.59 & 29.83 & A_W \\
\hline 37.58 & 39.49 & 33.76 & 33.76 & 36.31 & 36.31 & 34.39 & 27.39 & 25.48 & $A \_D$ \\
\hline 30.37 & 31.08 & 34.73 & 35.17 & 30.72 & 33.84 & 29.92 & 26.36 & 19.86 & W_C \\
\hline 32.15 & 29.96 & 39.25 & 39.25 & 29.75 & 37.58 & 28.81 & 29.35 & 22.96 & W_A \\
\hline 90.45 & 87.26 & 75.80 & 75.16 & 80.89 & 80.89 & 85.99 & 77.07 & 59.24 & W_D \\
\hline 32.15 & 30.72 & 35.89 & 34.55 & 30.28 & 32.41 & 32.06 & 29.65 & 26.27 & D_C \\
\hline 31.21 & 31.63 & 38.73 & 39.87 & 32.05 & 34.34 & 31.42 & 32.05 & 28.5 & D_A \\
\hline 88.81 & 84.41 & 76.95 & 76.95 & 75.59 & 77.63 & 86.44 & 75.93 & 63.39 & D_W \\
\hline 46.59 & 45.16 & 44.52 & 44.72 & 42.95 & 42.55 & 43.03 & 39.65 & 31.37 & متوسط \\
\hline
\end{tabular}




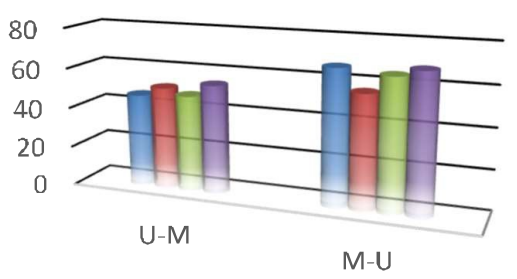

$\square$ GFK $\square$ TCA $=$ SCA $=$ SRSA

(شكل - (D): مقايسه دقت طبقهبندى بر روى هايكاه داده اعداد با

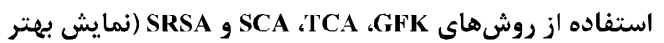

$$
\text { بdصورت رنكى) }
$$

(Figure-5): The comparison of the classification accuracy on Digit dataset using GFK, TCA, SCA and SRSA methods (Best viewed in color)
يك روش تطبيق و تعميم دامنهها است كه SCA

اختلاف بين دامنهها را كمينه، اختلاف بين نمونهها در بريق ردههاى مختلف را بيشينه و اختلاف بين نمونههاى هر رده

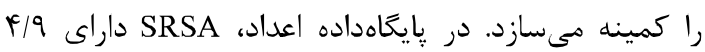
متوسط بهبود دقت نسبت به SCA و در زايكاهداده آفيس و كالتك، داراى بr/Fr متوسط بهبود دقت و عمدهترين دليل برترى SRSA نسبت به SCA استفاده از تطبيق زيرفضا براى دئ دمون كاهث اختلاف بين دامنهها است.

نمودارهاى مربوط به مقايسه دقت طبقهبند بر روى برى

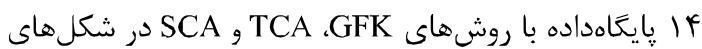
(ه) (

(شكل - (): مقايسه دقت طبقهبندى بر روى يايخاه داده آفيس و كالتك با استفاده از روشهاى GCK و SCA TCA SRSA

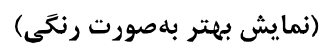

(Figure-6): The comparison of the classification accuracy on Office \& Caltech dataset using GFK, TCA, SCA, and SRSA (Best viewed in color)

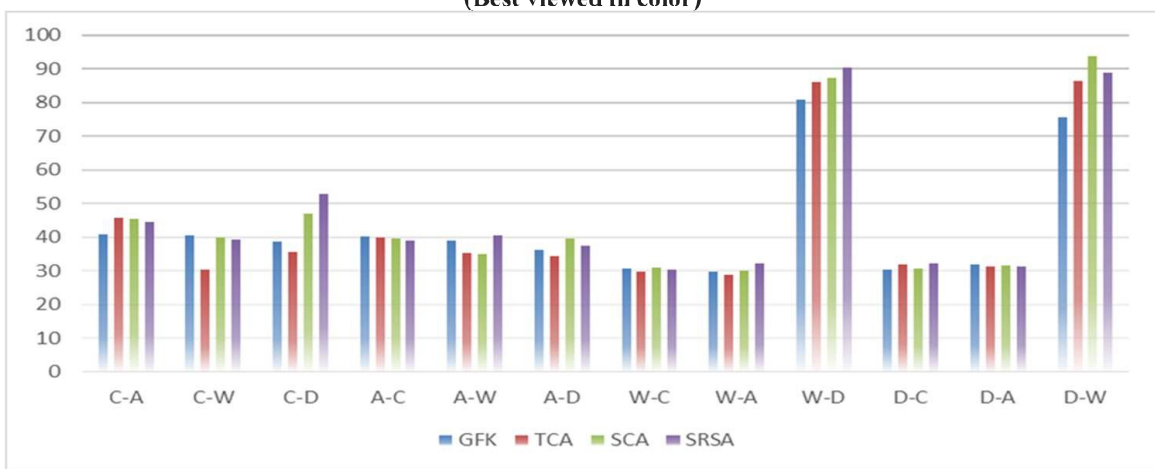

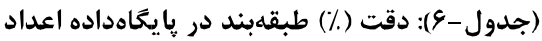

\begin{tabular}{|c|c|c|c|c|c|c|c|c|c|}
\hline & & & e avose & He crassmiticat & 1 accuis acy ois & Ell tataset & & & \\
\hline SRSA & SCA (2016) & SDA (2015) & $\mathrm{S} \Lambda$ (2013) & GFK (2012) & DAM (2012) & TCA (2011) & PCA (2002) & $\mathrm{NN}$ & Dataset \\
\hline 54.35 & 48 & 35.70 & 41.50 & 46.45 & 42.69 & 51.05 & 44.95 & 44.7 & U_M \\
\hline 68.56 & 65.11 & 65 & 63.95 & 67.22 & 52.83 & 56.28 & 66.22 & 65.94 & M_U \\
\hline 61.46 & 56.56 & 50.35 & 52.73 & 56.84 & 47.76 & 53.67 & 55.59 & 55.32 & متوسط دقت \\
\hline
\end{tabular}

(Table-6): The classification accuracy on Digit dataset

نقش نمونههايى از دادههاى منبع را كه عامل ايجاد اختلاف

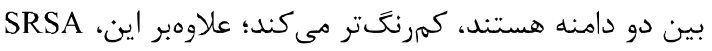

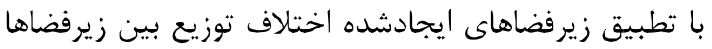

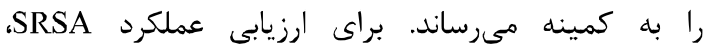

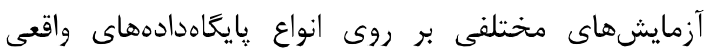

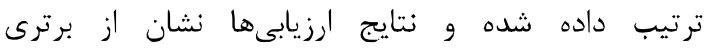

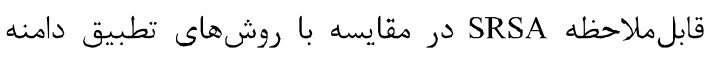

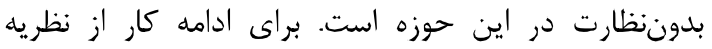

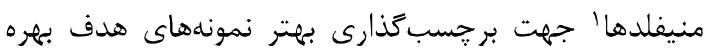

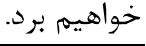

${ }^{1}$ Manifolds

\section{و- نتيجلهيرى}

در اين مقاله يك روش بدوننظارت جهت حل مسأله شيفت

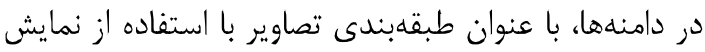

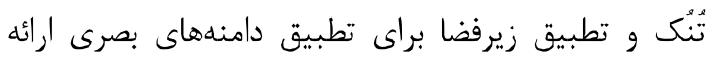

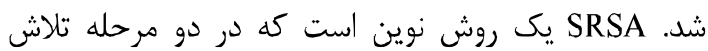

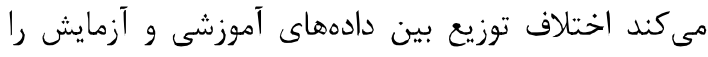

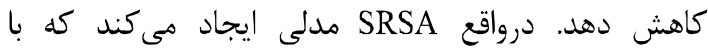

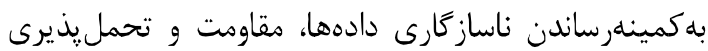

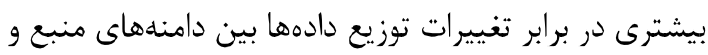

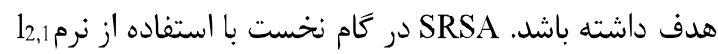


[15] X. Li, M. Fang, J. J. Zhang and J. Wu, "Sample selection for visual domain adaptation via sparse coding", Signal Processing: Image Communication, vol. 44, pp. 92-100, 2016.

[16] K. Saenko, B. Kulis, M. Fritz and T. Darrell, "Adapting visual category models to new domains", Proceedings of the European Conference on Computer Vision, pp. 213-226, 2010.

[17] G.Griffin, A. Holub and P. Perona, "Caltech256 object category dataset", Technical Report7694, 2007.

[18] J. J. Hull, "A", IEEE Trans. Pattern Anal. Mach. Intell, vol. 16, no. 5, pp. 550-554, 1994.

[19] Y. LeCun, L. Bottou, Y. Bengio, P. Haffner, "Gradient-based learning applied to document recognition", Proc. IEEE, vol. 86, no. 11, pp. 2278-2324, 1998.

[20] L. Duan, D. Xu, I.W. Tsang, "Domain adaptation from multiple sources: a domain-dependent regularization approach", IEEE Trans. Neural Netw. Learn. Syst, vol. 23, no. 3, pp. 504-518, 2012.

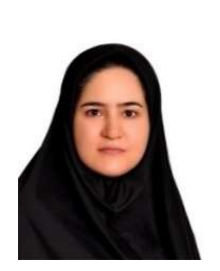

$$
\text { فريماه شرافتى مدرى كارشناسى خود }
$$

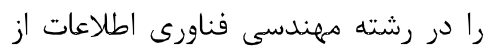

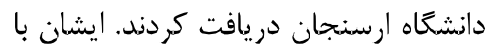

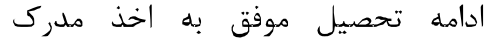

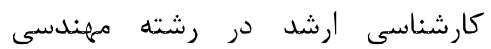

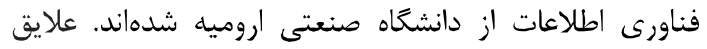

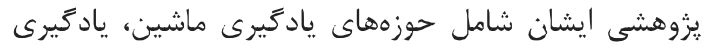
انتقالى است.

$$
\text { نشانى رايانامه ايشان عبارت است ازئ }
$$

\section{farimah.sherafati@it.uut.ac.ir}

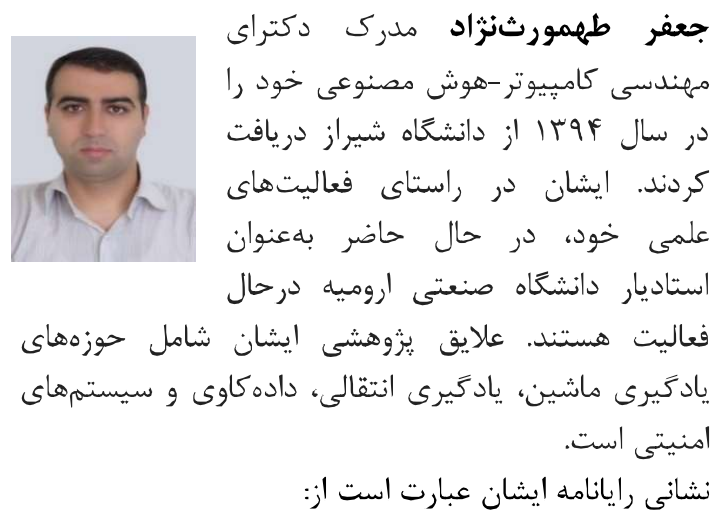

j.tahmores@it.uut.ac.ir

\section{7- References}

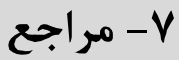

[1] Y. Zhang, T. Liu, M. Long, and M. I. Jordan, "Bridging Theory and Algorithm for Domain Adaptation", arXiv preprint arXiv:1904.05801, 2019.

[2] S. Rezaei and J. Tahmoresnezhad, "Discriminative and domain invariant subspace alignment for visual tasks", Iran Journal of Computer Science, pp. 1-12, 2019.

[3] W. Kumagai and T. Kanamori, "Risk bound of transfer learning using parametric feature mapping and its application to sparse coding”, Machine Learning, pp. 1-34, 2019.

[4] I. Jolliffe "Principal component analysis", Wiley, vol. 2, pp. 433-459, 2002.

[5] M. Jing, J. Li, J. Zhao, and K. Lu, "Learning distribution-matched landmarks for unsupervised domain adaptation", In International conference on database systems for advanced applications, pp. 491-508, 2018.

[6] A. Li, D. Chen, Z. Wu, G. Sun, and K. Lin, "Selfsupervised sparse coding scheme for image classification based on low rank representtation", PloS one, Vol. 13(6), e0199141, 2018.

[7] A. Mirjalili, V. Abootalebi, M. T. Sadeghi, "mproving the performance of sparse representation-based classificr for EEG classification," JSDP, pp. 43-55, 2015.

[8] X. Li, M. Fang, J. J. Zhang and J. Wu, "Sample selection for visual domain adaptation via sparse coding", Signal Processing: Image Communication, vol. 44, pp. 92-100, 2016.

[9] B. Gong, Y. Shi, F. Sha and K. Grauman, "Geodesic flow kernel for unsupervised domain adaptation", Proceedings of the IEEE Conference on Computer Vision and Pattern Recognition, pp. 2066-2073, 2012.

[10] S. J. Pan, I. W. Tsang, J. T. Kwok and Q. Yang, "Domain adaptation via transfer component analysis", IEEE Trans. Neural Netw, vol. 22, no. 2, pp. 199-210, 2011.

[11] B. Fernando, A. Habrard, M. Sebban, and T. Tuytelaars, "Unsupervised visual domain adaptation using subspace alignment", in Proc. IEEE International Conference on Computer vision, pp. 2960-2967, 2013.

[12] M. Ghifary, D. Balduzzi, W. B. Kleijn, and M. Zhang, "Scatter component analysis: A unified framework for domain adaptation and domain generalizayion", IEEE Transactions on Pattern Analysis and Machine Intelligence, pp. 1-1, 2016.

[13] B. Sun and K. Sacnko, "Subspace distribution alignment for unsupervised domain adaptation", in Proc. British Machine Vision Conference, 2015.

[14] J. Tahmoresnezhad and S. Hashemi, "Visual domain adaptation via transfer feature learning", Knowledge and Information Systems, vol. 50, no. 2 , pp. $585-605,2017$ 